\title{
REASSESMENT OF THE EUROPEAN MODE 1 OCCURRENCES: ELEMENTS FOR THEIR TECHNOLOGICAL DEFINITION AND INTERPRETATION
}

\author{
REVISIÓN DEL MODO 1 EUROPEO: ELEMENTOS PARA SU DEFINICIÓN \\ TECNOLÓGICA Y SU INTERPRETACIÓN
}

FERNANDO DÍEZ MARTÍN (*)

\begin{abstract}
The concepts of production and standardization are used to technologically characterize European Lower and Middle Pleistocene lithic assemblages without handaxes. It is argued that many of the sites without bifaces dated after 500 $\mathrm{Ka}$. are examples of a Mode 2 technology. On the other hand, several factors, including lithic variability and migrations, are considered to provide explanations for Mode 1 occurrences.
\end{abstract}

\section{RESUMEN}

Los conceptos de producción y configuración son utilizados para caracterizar técnicamente los conjuntos líticos del Pleistoceno inferior y medio europeo sin bifaces, mostrando que la mayor parte de estos yacimientos, datados con posterioridad a los $500 \mathrm{Ka}$., forman parte integrante del Modo 2. También se analizan y discuten los factores de variabilidad que pueden asociarse a los conjuntos con tecnología del Modo 1 que aún se observan en el registro.

Key words: Lower and Middle Pleistocene. Europe. Mode 1. Production. Standardization. Lithic variability. Migrations.

Palabras clave: Pleistoceno inferior y medio. Europa. Modo 1. Producción. Configuración. Variabilidad lítica. Migraciones.

(*) CRAFT Research Center, Indiana University. 419, N. Indiana Ave., Bloomington, IN, 47405, USA. Correo electrónico: fdiezmar@ indiana.edu

Recibido: 27-IX-01; aceptado: 2-IV-02.

\section{INTRODUCTION}

The idea of the existence of two parallel technological traditions during the European Lower Palaeolithic (pebble tools and Acheulean) goes back to the first half of the 20th century. Breuil's (1932) comprehensive publication about the Clactonian industry, to which the Tayacian (Lumley 1971) and the non-biface Central European assemblages (Kretzoi \& Vertés 1965) were later assimilated, permitted researchers to establish a relation between core/flake and Acheulean industries, which were assumed to be contemporaneous during the Middle Pleistocene. In addition to this dualistic perception of technology on a synchronic level, chopper assemblages also represented an older stage of human evolution, related to the African Palaeolithic sequence recorded at Olduvai Gorge (Leakey 1971) (1). The description in Europe of numerous sites furnishing long chronologies and yielding chopping tool industries seemed to support this perspective (Bonifay \& Vandermeersch 1991).

In the 1990's the scenario of an early occupation of Europe with pre-Acheulean industries was drastically contradicted by scholars who cast doubt on the authenticity of all the Lower Pleistocene archaeological sites, rejected the validity of the long chronologies and proposed a more plausible colonization framework (according to palaeoanthropological, faunal, geological and archaeological data) at around $500 \mathrm{Ka}$. (Roebroeks \& Van Kolfschoten 1994, 1995). Since then, the debate about when and

(1) A good example of this pebble industry perspective can be found in Tieu (1991). 
with what technology the first colonization of Europe took place flourished after the publication of new dates in the Spanish site of Gran Dolina level 6, in Atapuerca (Parés \& Pérez-González 1995). This site revitalized the discussion and opened the doors to a possible human presence in the Mediterranean region at earlier times than in Northern latitudes (Dennell \& Roebroeks 1996).

Nowadays there are some archaeologists who openly consider irrelevant a human presence in Europe prior to the Northern colonization (Gamble 1999: 119), or still have doubts about the scenario shown by Atapuerca (Roebroeks \& Van Kolfschoten 1998). On the other hand, new data may support the idea (Villa 1983: 12-14) that the first human presence in Europe could go back to around $1 \mathrm{Ma}$. (Gabunia et al. 2001; Manzi et al. 2001; Oms et al. 2000).

One of the essential aspects of this debate is related to the characteristics of the first technology that arrived into Europe. This particular issue has been frequently used to stress the doubts still existing about the human presence on this continent prior to OIS 13. Some authors (Dennell \& Roebroeks 1996: 539) ask how it is possible that, in a geographic framework dominated $1 \mathrm{Ma}$. ago by the Acheulean both in Northern Africa (Raynal et al. 2001) and the Near East (Bar-Yosef 1998), the oldest sites of Southern Europe exhibit a more expedient Mode 1 technology. Others suggest that the observed differences simply reflect answers to different needs or environments (Villa 2001: 120). In this context, the use of technological characterizations as chronological markers would not have any validity, in view of the fact that less progressive assemblages are not only seen in the Lower Pleistocene sites, but are extensively present (as cited above) during the Middle Pleistocene period (Dennell \& Roebroeks 1996: 539-540; Villa 2001: 119), contemporaneous with the Acheulean and, in some cases, interstratified within it (Mussi 1995: 31).

The aim of this contribution is to state that the use of the last argument, claiming for a current presence of Mode 1-like assemblages during the Middle Pleistocene, as a critique of the mature Europe hypothesis (Carbonell et al. 1995) lacks theoretical support and rests on an obsolete epistemological scheme that needs revision (Wenban-Smith 1998: 93). The problem consists in using the handaxe presence or absence as an absolute reference and, therefore, including in the same category all the European core and flake industries prior to the
Upper Pleistocene. This perspective shows homogeneity (e.g. labelling such remarkably different assemblages as Bilzingsleben and Monte Poggiolo as examples of the same Mode 1 technology [Villa 2001: 119]) and, then continuity, where probably a more complex array of archaeological phenomena, as yet unexplained, are present. This paper first defines the technological and conceptual framework of reference chosen here and, then, briefly presents the most important non-handaxe assemblages of the European Lower and Middle Pleistocene, followed by a discussion based on the available information.

\section{THE TECHNOLOGICAL MODES 1 AND 2: PRODUCTION VERSUS STANDARDIZATION}

Graham Clark's (1969: 23) lithic classification model of the Technological Modes has been used by a number of workers in different ways. The main advantage of this model is that it allows us to characterize objectively general technological behaviours and to establish connexions among them, in order to create regional synthesis (Schick 1994: 575). It is necessary to acknowledge that the Modes succession does not imply a gradualist chronological progression from simple to complex (Torrence 1989), or (contra Foley 1987) an automatic correlation between diagnostic technical characters and different biological species, as several works confirm (Cosgrove 1999; Schick 1994; Bar-Yosef \& Kuhn 1999).

Mode 1 is characterized as a least effort technology (Isaac et al. 1997: 296), defined extensively in a number of contributions (Toth 1985, 1987; Ludwig and Harris 1998; Semaw 2000). These works put in evidence that one of the fundamental goals of lithic production are flakes with natural cutting edges (Toth 1985: 118). The recognized reduction schemes (unifacial, bifacial, multifacial and discoid) represent the flaking by-products adapted to the original blank forms (Toth 1985: fig. 5). The retouch (marginal and non-organized) reflects the expedient character of this technology.

Acheulean Mode 2 has been technically redefined by principles like standardization and predetermination (Texier \& Roche 1995). The first one refers to a systematic configuration of specific forms by the use of recurrent technical gestures, which imply the delineation of natural edges through flaking and retouching and its adaptation

T. P., 59, n. $^{\circ} 2,2002$ 


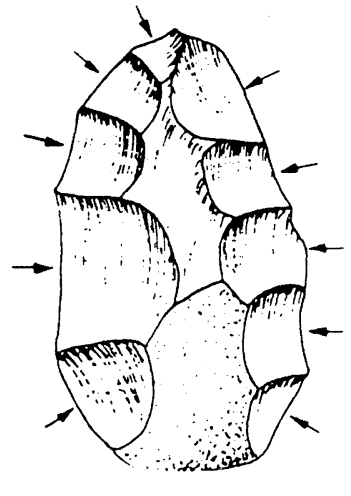

a1

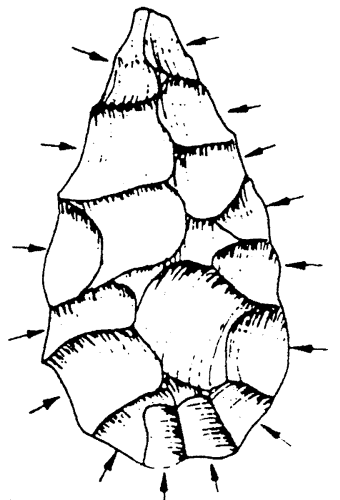

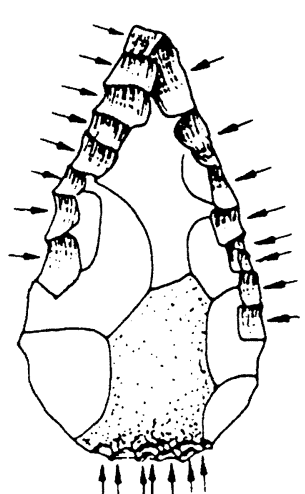

114111

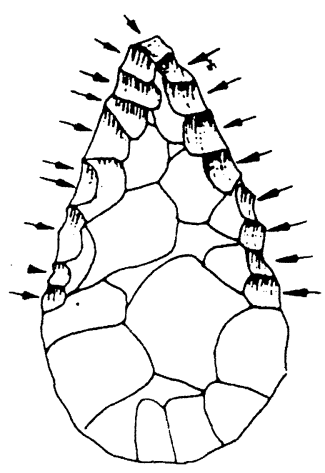

a2

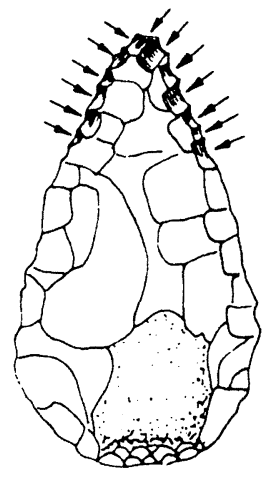

a3

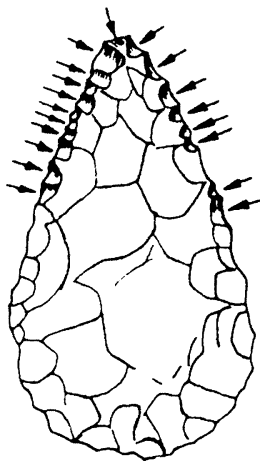

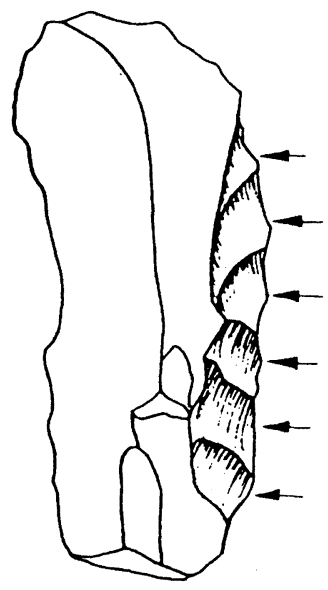

b 1

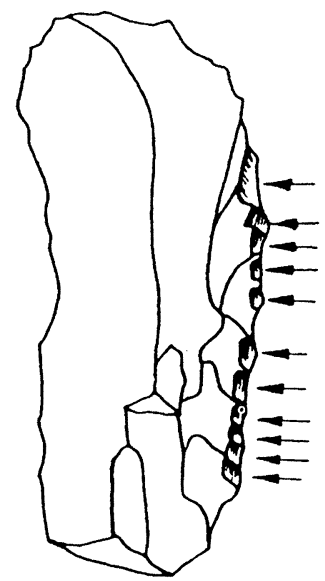

b2

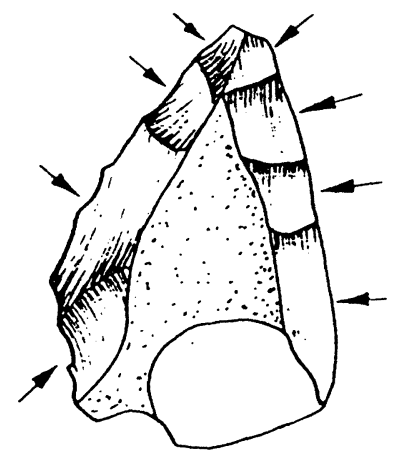

c1

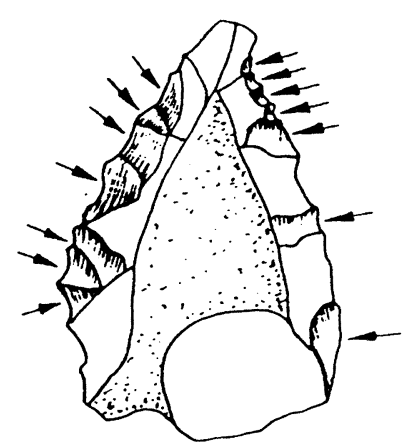

c2

Fig. 1. Tool configuration stages: a. large format (handaxe); b. medium format (scraper); c. small format (point). (Adapted from Carbonell et al. 1999a).

to the blank's characteristics: large format -handaxes and cleavers- or small format-scrapers, points or Upper Palaeolithic types- (Carbonell et al. 1999a: 321-323) -fig. 1-. Mode 2 is often characterized by the production of large flakes. Some workers (for example Texier \& Roche 1995: 408; Carbonell et al. 1999a: 312) have paid attention to the fact that the use of this technique, besides the requirement 


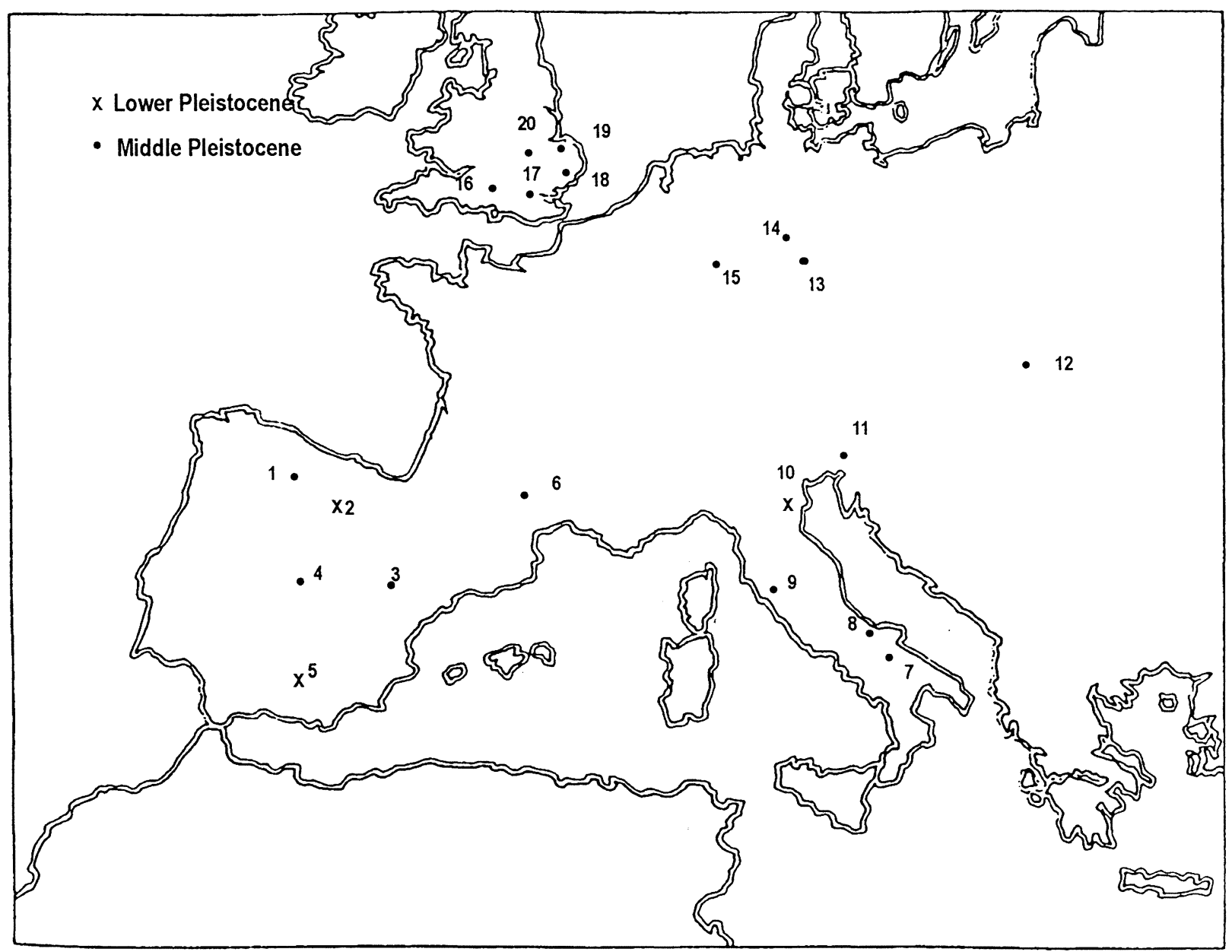

Fig. 2. Map of European sites cited in the text: Spain: 1, Los Llanos (San Quirce de Río Pisuerga); 2, Atapuerca TD6; 3, Cuesta de la Bajada; 4, Áridos del Jarama; 5, Fuente Nueva 3 \& Barranco León; France: 6, Arago; Italy: 7, Venosa Loreto \& Notarchirico; 8, Isernia la Pineta; 9, La Polledrara; 10, Monte Poggiolo; 11, Visogliano; Hungary: 12, Vértesszölös; Germany: 13, Bilzingsleben; 14, Schöningen; 15, Miesenheim; Britain: 16, Boxgrove; 17: Swanscombe; 18, Clacton; 19, Barnham; 20, High Lodge.

of a good knowledge of certain flaking principles (Jones 1994: 262-263), may sometimes imply a core preparation in such a way that the flake form is predetermined before its detachment. Standardization and predetermination reflect a succeeding transformation from a prior conceptual scheme (desired object) to a final operative scheme (technique control) that is not seen in Mode 1.

In this paper, rather than making the Modes equivalent to Oldowan or Acheulean, the concepts of production and standardization are used to define Mode 1 and Mode 2 technologies. The Mode 2 industrial group goes beyond, from this perspective, the presence or absence of a particular type-fossil (in this case, the handaxe). It is worth pointing out however, that the existence of a non-bifacial element within Mode 2 is not a new concept (WenbanSmith 1998: 93).

\section{THE LOWER PLEISTOCENE SITES (>780 Ka.)}

The analysis presented here excludes those assemblages showing substantial doubts about their validity: absence of context, serious chronological problems or controversial diagnosis about the human authorship of lithic artefacts (a comprehensive approach to most of these occurrences and their characteristics can be found in Bonifay \& Vander- 
meersch 1991 or Roebroeks \& Van Kolfschoten 1995). The sites that, in the state of our knowledge, can be more firmly included in this section are:

- Fuente Nueva 3 \& Barranco León (Spain). These sites are located in the lacustrine sediments of Baza Formation, very rich in macromammal assemblages of Lower Pleistocene (Martínez Navarro et al. 1997). Recently (Oms et al. 2000), 110 samples in the stratigraphic sequence have been analysed, showing negative polarity. Palaeomagnetic data, along with faunal data, put in evidence that the lithic artefacts can be located within the Matuyama reversed chron, possibly prior to $1,07 \mathrm{Ma}$. (if a preJaramillo epoch is accepted, as the microfauna indicates).

The lithic collections, recovered in low energy contexts, total 161 objects, to which another 54 items located on the surface must be added (Oms et al. 2000: tab. 1). The flaked pieces are made in local good quality flint and chert (Roe 1995: 8). The observed data show a clear preference for production processes, with unifacial and discoid cores of small dimensions $(4,18 \%)$, flakes with no prepared butts $(22,79 \%)$ and abundant debris less than $2 \mathrm{~cm}$ long $(42,79 \%)$. Formal retouch is not present, although trimmed flakes, recorded in high numbers $(15,34 \%)$, may reflect a marginal edge transformation due to use (Martínez Navarro et al. 1997: 618). Cited data suggest a lithic activity focused on the production of flakes and influenced by the good quality of the siliceous raw material and the average dimensions of the cobbles (between 10 and $15 \mathrm{~cm}$ ).

- Gran Dolina TD6. Gran Dolina is one of the sites located in the Sierra de Atapuerca complex (Spain). It is an $18 \mathrm{~m}$. karstic infilling, divided into 11 levels that can be bracketed between the upperLower and Middle Pleistocene. The Matuyama/ Bruhnes polarity shift has been recognized in TD7 (Parés \& Pérez-González 1999: 338), therefore TD6 Aurora Stratum (bearing human fossils, fauna and lithic artefacts) has been assigned to the Matuyama reversed chron. This palaeomagnetic framework is in accordance with the micromammal assemblage (Cuenca-Bescós et al. 1999: 370). Palaeoenvironmental information (García-Antón 1995 ) could pinpoint to climatic transitions OIS 2221 or OIS 20-19, between 830 and $795 \mathrm{Ka}$.

The Aurora Stratum has yielded a total of 268 lithic artefacts, made in seven different types of local rocks, mainly flint and quartzite (Carbonell et al. 1999b: 657). Along with 6,9\% of cobbles, 7,1\% of the objects are cores representing unifacial, multifacial and discoid flaking schemes, with no traces of preparation. The scarcity of nuclei has been related to the selective or already prepared transportation of cobbles into the cave (cf.: 665). However, some refitting among the artefacts may suggest certain steps of the reduction process. Among these, 27 items (mainly flint) have been transformed using a casual retouch that produces denticulate edges (cf.: tab. 5). In sum, this assemblage marks a main production behaviour linked to a marginal and non-systematic configuration of small format flakes (cf.: 683-686).

- Ca'Belvedere di Monte Poggiolo (Italy). The deposits of this site belong to a Lower Pleistocene sequence (Antoniazzi et al. 1988): marine blue clays at the bottom, dated by ESR at about 1,5 Ma. (Yokoyama et al. 1992), followed by coastal yellow sands bracketed between 1-0,9 Ma. (Azzaroli et al. 1988). The archaeological site is located in fluviatile detritic sediments that have been geologically related to the yellow sands. Palaeomagnetic and ESR analyses on quartz grains have furnished an Upper Matuyama age, around $800 \mathrm{Ka}$. (Peretto et al. 1998).

The lithic industry consists of 1319 objects made in flint of diverse quality. The cores represent a $11,59 \%$ of the assemblage and show a very simplistic flaking model on one or two surfaces and a very low rate of exploitation $(20 \%$ of the cobbles show only one scar). The $88,40 \%$ left are flakes (almost half of them complete), detached in the first steps of the reduction sequence and with no platform preparation. The retouched objects ( 7 denticulates and 5 scrapers) represent $0,9 \%$ of the whole collection and exhibit a poor transformation of the natural edges. The lithic analysis and the information provided by the 76 analysed refittings put forward a technological process based on the opportunistic exploitation of flint cobbles. Use-wear analysis suggests that (cf.: 454) in addition to the intense flake production, some subsistence activities took place at the locality.

\section{THE MIDDLE PLEISTOCENE SITES (<78 $\varnothing$ Ka.)}

A sample of the most representative assemblages without bifaces of this period has been chosen. 


\begin{tabular}{|c|c|c|c|c|c|c|c|c|}
\hline \multirow[t]{2}{*}{ sites } & \multicolumn{2}{|c|}{ general lithics } & \multicolumn{6}{|c|}{$\%$ small format tool types (no.) } \\
\hline & $\begin{array}{c}\text { artefacts } \\
\text { (total) }\end{array}$ & $\begin{array}{c}\text { core/flakes ratio } \\
(\%)\end{array}$ & $\begin{array}{c}\text { scrapers/ } \\
\text { end scrapers }\end{array}$ & denticulates & $\begin{array}{c}\text { notches/ } \\
\text { clactonian notches }\end{array}$ & $\begin{array}{l}\text { borers/ } \\
\text { burins }\end{array}$ & points & $\begin{array}{c}\text { retouched/ } \\
\text { trimmed objects }\end{array}$ \\
\hline Fuente Nueva 3-BL & 215 & $4.18 / 95.81$ & - & - & - & - & - & $15.34(33)$ \\
\hline Atapuerca TD6 & 268 & $23.21 / 73.78$ & $2.61(7)$ & $7.08(19)$ & - & - & - & $0.74(2)$ \\
\hline Monte Poggiolo & 1319 & $11.59 / 88.40$ & $0.37(5)$ & $0.53(7)$ & - & - & - & - \\
\hline High Lodge & 1510 & $3.85 / 96.15$ & $1.72(26)$ & $0.33(5)$ & $0.39(6)$ & - & - & $3.31(50)$ \\
\hline Bilzingsleben & 15300 & $15.1 / 84.9$ & $3.77(577)$ & - & $1.58(242)$ & $0.52(80)$ & $2.11(323)$ & $2.71(415)$ \\
\hline Vértesszölös & 8890 & - & $24.07(2140)$ & - & $1.61(144)$ & $3.35(299)$ & $0.49(44)$ & - \\
\hline Notarchirico a & 950 & $45.9 / 54.1$ & $11.89(113)$ & $13.36(127)$ & - & $0.94(9)$ & - & $5.15(49)$ \\
\hline
\end{tabular}

Tab. 1. Small format retouched industry in Lower and Middle Pleistocene European sites (source: Oms et al. 2000, Carbonell et al. 1999b, Peretto et al. 1998, Ashton 1992, Mania 1988, Piperno 1999).

In some cases the chronological framework still is under revision, but all of them are currently cited in the literature.

- Isernia la Pineta (Italy). This site has been excavated in lacustrine and fluvial sediments and has yielded a spectacular macrofaunal assemblage and a rich lithic collection. One of the most controversial aspects of this site is related to chronology. $\mathrm{K} /$ Ar analysis on sanidine crystals furnished an age of $736 \pm 40 \mathrm{Ka}$. for level 3a, consistent with another one around $500 \mathrm{Ka}$. taken in younger volcanic tuffs at the top of the sequence (Coltorti et al. 1982). However, the biostratigraphic correlation shows (Roebroeks \& Van Kolfschoten 1994, Mussi 1995: 36) an age closer to the second half of the Middle Pleistocene, around $500 \mathrm{Ka}$., for the archaeological occurrences. Recently, through the macro mammal assemblage, some palaeontologists have suggested an age of about $600 \mathrm{Ka}$. (Petronio \& Sardella, 1999), which is in agreement with recent $\mathrm{K} / \mathrm{Ar}$ dates (Coltorti et al. 2000) (2).

The lithic collection (5.551 objects) is made in local flint and limestone (Sozzi et al. 1994). Flint nodules are small with many fracture planes, whereas limestone cobbles are larger and scarcely flaked. The flint flaking system is elementary, based mainly on a bipolar technique and direct percussion, generating a large number of small flakes and fragments less than $4 \mathrm{~cm}$ of length. The morphology of many modified flakes has been identified as denticulate (Crovetto 1994: 261), representing 20\% of the series (Anconetani et al. 1992), although experimental studies have confirmed that these forms are in fact unintentional by-products result-

(2) Coltorti, M.; Corrado, S.; Di Bucci, D.; Marzoli, A.; Saso, G.; Peretto, C.; Ton-That, T. \& Villa, I. 2000: «New chronostratigraphical and palaeoclimatic data from Isernia la Pineta site». In Subcommission on European Quaternary Stratigraphy (SEQS) meeting: The Plio-Plieistocene boundary and the Lower-Middle transition: tupe areas and sections. Abstracts. (Bari, Italy, 25-29 September, 2000). ing from the flaking system (Crovetto et al. 1994: 151). Technically speaking, the assemblage can be considered a typical ad hoc and non-systematic exploitation of deficient raw materials.

- High Lodge (Britain). The site is located in sand and clay Pleistocene sediments, corresponding to a fluviatile system. Lithostratigraphic and faunal data have shown that the archaeological occurrences can be dated at the end of a warm period, immediately before the Anglian glaciation (Roberts et al. 1995: 169), at the end, therefore, of OIS 13 (between 524 and $478 \mathrm{Ka}$.).

The whole lithic collection was elaborated in high quality flint. Cores are exploited following unifacial, bifacial and multifacial techniques, which often are combined in the same nodule. The flakes produced, whose dimensions vary between 20 and $70 \mathrm{~mm}$, are thick and with plain platforms. The retouched products -including the characteristic technique of the flaked flakes (Ashton 1992: 146)- belong to a certain variety of diversified models (cf.: tab 11.13), with the predominance of standardized scrapers (Ashton \& McNabb 1992: 166) (Fig. 3a).

- Bilzingsleben (Germany). This site is located on the base of travertine sediments, in a $+27 \mathrm{~m}$. level of a Pleistocene glacial terrace. Sediments were deposited during a warm period that absolute datings, U-series and ESR on rhino teeth (Schwarcz et al. 1988), bracketed between 300-400 $\mathrm{Ka}$. This information cannot show with exactitude whether we are dealing with OIS 11 (Mania 1995: 90) or OIS 9.

The abundant lithic industry is $93 \%$ made in semi-local flint, which has been used to produce small size flakes (Mania 1988: 1058). Less common, quartzite, quartz and limestone have been used as hammerstones or core/choppers of larger dimensions. Within the flint implements, there have 

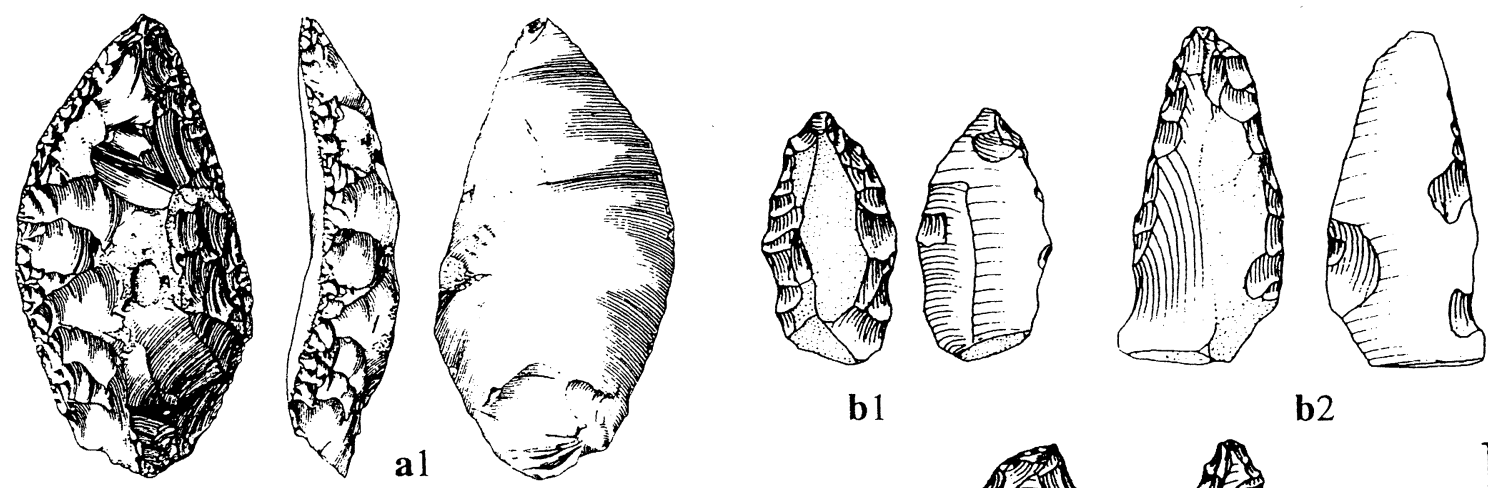

b1

b2
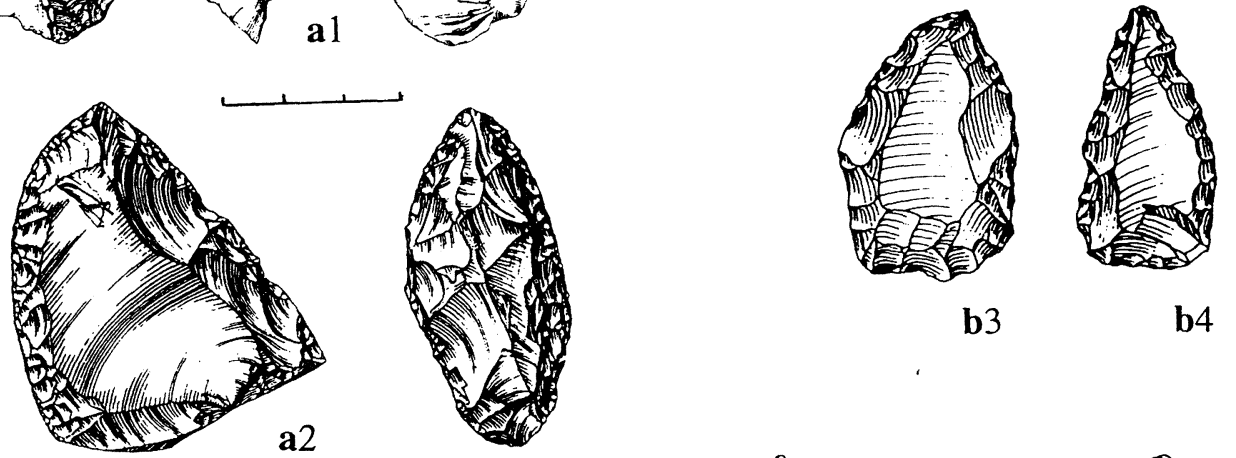

b3

b4

a 3
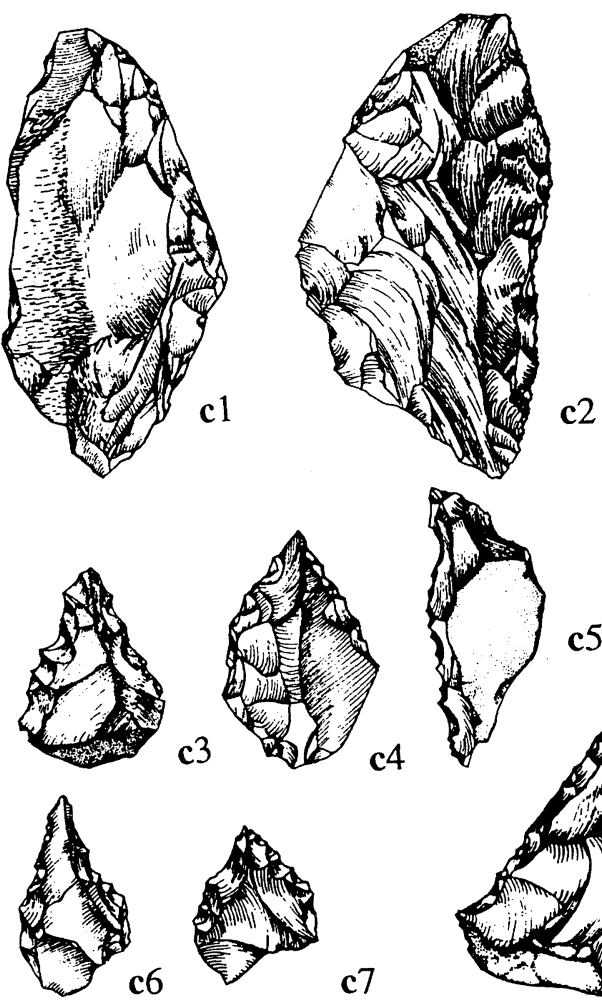

c7
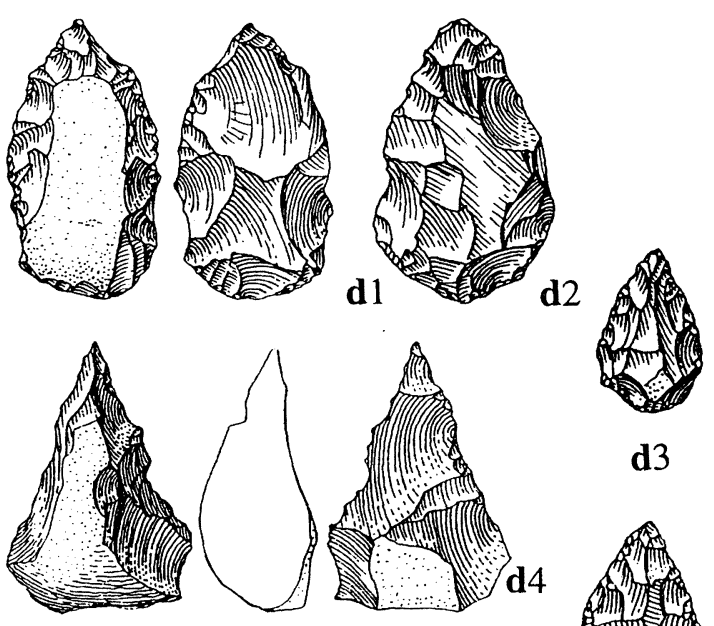

d3
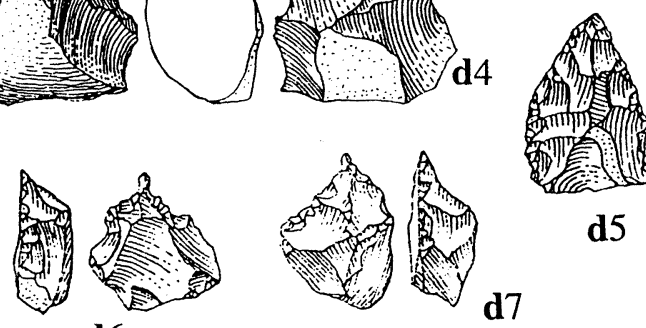

d6
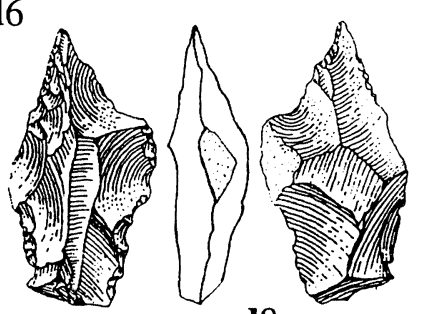

c8

Fig. 3. Middle Pleistocene standardized flake tools: a. High Lodge; b. Notarchirico Alpha; c. Vértesszölös; d. Bilzingsleben (Adapted from Roberts et al. 1995, Piperno 1999, Dobosi 1990, Mania 1995). 
been documented prepared cores that have produced levallois-like flakes, along with other nonsystematic nuclei (Svoboda 1987: 224). Due to the excellent quality of the siliceous materials, $61 \%$ of the assemblage is made of flakes and $10,65 \%$ are retouched flakes (between 18 and $35 \mathrm{~mm}$ ) made into an important variety of diversified tools, mainly points -Tayac, Quinson or bifacially retouched that represent an optimal solution for small size products (Carbonell et al. 1999: 322)-, scrapers and end scrapers (Fig. 3d).

- Vértesszölös (Hungary). The archaeological sites are located in travertine and sandy sediments in the $+60 \mathrm{~m}$. Átalér river terrace (Valoch 1995: 77). $\mathrm{Th} / \mathrm{U}$ radiometric datings, showing some contradictions, have furnished dates between 350 and 245 Ka. (Kretzoi \& Dobosi 1990) that, in connection with the faunal remains, might be related to OIS 9.

The seven fertile levels have yielded a total of 8.890 lithic objects, made in small quartzite/quartz pebbles, flint and limestone (Dobosi 1988: 1048). The extremely small size of the flaked cobbles implies that they can be classified as chopping tools $(44,64 \%)$. Some of the cores $(3,07 \%)$ have been identified as prepared nuclei (Svoboda 1987: 223). An important number of flakes (with average dimensions of 2,6 cm) have been transformed -using a carefully done retouch (Kretzoi \& Vértes 1965: 80 ) - into standardized forms, mostly scrapers $(24,07 \%$ of all retouched implements) and other Upper Palaeolithic type objects. The remarkably small dimensions of the raw material have not been an obstacle to perform a rather extensive systematic transformation of natural edges into diversified forms (Fig. 3c).

\section{THE INDUSTRIES WITHOUT BIFACES IN THE EUROPEAN RECORD: GENERALIZED MODE 1?}

This review of the most significant archaeological evidence without handaxes suggests that the assemblages representing Mode 1 technology (based on the pursuit of natural cutting edges by core flaking and with scarce evidence of small format tool standardization) can be restricted to the cited examples that belong to the Lower Pleistocene (Fuente Nueva 3 \& Barranco León, Atapuerca TD6 and Monte Poggiolo). The discussed information allows a comparison with some of the African clas- sic Mode 1 sites or those sites described in Eastern Asia (Schick et al. 1991, Schick \& Zhuan 1993).

With regard to the examples seen in the Middle Pleistocene, excepting Isernia's Mode 1 industry, all of them can be related to the standardization and diversification processes taking place among Mode 2 technologies, with the peculiarity of the lack of bifaces. One of the most significant examples of the last group is High Lodge and its relation to the Clactonian industry (to which known sites like Clacton and Barnham should be added). The suggestion that this techno-complex simply constitutes a preparatory industry of the Acheulean was proposed by Ohel (1979). One reason for doubts about this hypothesis was the absence of contemporaneity evidence between Clactonian and Acheulean (Newcomer 1979). Nowadays this evidence might have been found, as suggested at sites like Barnham (Ashton et al. 1994). Differences between both industrial groups would only reflect local raw material availability variations across the landscape (cf.: 589) or over time (Wenban-Smith 1998: 96). It is important to recall that the High Lodge assemblage, showing a high degree of standardization among the small tools, was once, before the last chronological revision, related to the Mousterian transition (Ashton \& McNabb 1992: 165).

Something similar occurs in Vértesszölös, associated first with the Tata Mousterian industry (Vértes 1975: 288). This assemblage is an example, as well as Bilzingsleben or Schöningen (Mania 1995: 95, Thieme 1999), of a configuration response adapted to the small size of the obtained products. Bilzingsleben is a good specialization reference example, with respect to both morphological diversity and selective raw material use (Mania et al. 1999: 303). A similar example of a small size standardization scheme is observed in Visogliano 13-39 (Abbazzi et al. 2000: 1182) and Arago (Lumley 1976). The last mentioned site has been on some occasions compared to Bilzingsleben and Vérteszölös (Svoboda 1987), even though this site includes in all its archaeological horizons samples of bifaces (Villa 2001: 119). When comparing Middle Pleistocene occurrences with and without handaxes, the same technological traits are observed (Villa 2001: 119), provided that both groups exhibit the same technical resources and the same configuration solutions characterizing Mode 2.

It is necessary to point out, however, taking the chronological framework considered here, that a number of transitional aspects may be influencing

T. P., 59, n. ${ }^{\circ} 2,2002$ 


\begin{tabular}{|c|c|c|c|c|}
\hline site & age & mode & features & references \\
\hline Isernia la Pineta & OIS $15-13$ & Mode 1 & cores, fragments and flakes & Peretto, Ed. 1994 \\
\hline Notarchirico E, E1, a & OIS $13 ?$ & Mode 2 & $\begin{array}{l}\text { flakes/retouched flake tools } \\
\text { interstratified with handaxes }\end{array}$ & Piperno, Ed. 1999 \\
\hline High Lodge & OIS 13 & Mode 2 & standardization of smal tools & Ashton \& McNabb 1992 \\
\hline Visogliano $40-46$ & OIS $13-11$ & Mode 1 & flakes & Abbazzi et al. 2000 \\
\hline Visogliano 13-39 & OIS $13-11$ & Mode 2 & standardization of small tools & Abbazzi et al. 2000 \\
\hline Miesenheim I & OIS 13 & Mode 1 & cores and flakes & Turner 1999 \\
\hline Loreto & OIS 11 & Mode 2 & standardization of small tools & Crovetto 1991 \\
\hline Bilzingsleben & OIS 11-9 & Mode 2 & standardization of small tools & Mania et al. 1999 \\
\hline Schöningen & OIS 11 & Mode 2 & standardization of small tools & Mania 1995 \\
\hline Vértesszöllös & OIS $11-9$ & Mode 2 & standardization of small tools & Kretzoi \& Dobosi 1990 \\
\hline La Polledrara & OIS 9 & Mode 2 & standardization of small tools & Anzidei et al. 1989 \\
\hline Los Llanos & OIS 9? & Mode 1 & cores and flakes & Arnáiz \& Cuesta 1994 \\
\hline
\end{tabular}

Tab. 2. European Middle Pleistocene assemblages without handaxes.

some of these Middle Pleistocene sites. In recent years there is a tendency to expand the processes that mark the starting point of the Middle Palaeolithic to around $300 \mathrm{Ka}$. (Rolland 1999). From this period onward the archaeological record shows an important variability and some sites start showing traits of this transition (Moncel \& Combier 1992). This complex archaeological phenomenon continues an old debate (Bordes 1960; Roe 1982), in which some authors deny the existence of substantial differences between Modes 2 and 3 (Boëda 1991: 37), whereas others stress the technological continuum that this transition represents (Clark 1988: 236-237), a phenomenon in which sometimes the diagnostic levallois technique is absent of the record (Santonja 1995: 436).

\section{ADAPTATIONS OR MIGRATIONS: ON THE MEANING OF EUROPEAN MODE 1}

The young Europe hypothesis seems to match an inflexion in the archaeological record, which can be related to a colonization process at a continental level, in which Northern regions are also occupied (Gamble 1999: 121). It is currently accepted that since OIS 13, the species Homo heidelbergensis moved from Africa (Righmire 1996) into Europe with a well-developed Mode 2 technology, as can be seen in the British site of Boxgrove (Roberts $e t$ al. 1994). This species achieved adaptation, successful competition with other carnivores (Turner 1992) and settlement on a continuous basis (Dennell \& Roebroeks 1996). Finally, it locally evolved into Homo neanderthalensis (Arsuaga et al. 1996). In addition, the scarcity of the Lower Pleistocene archaeological record has been used to suggest that the first human radiation into Europe was in fact an intermittent adaptative attempt (Dennell \& Roebroeks 1996), carried out by pre-heidelbergensis species (Bermúdez de Castro et al. 1997, Manzi et al. 2001).

European sites show that the last and successful human occupation was made with a diversified Mode 2 technology, whereas the occurrences dated prior to $500 \mathrm{Ka}$. show only Mode 1 type technology so far. We must accept that the chronological boundary is not a suitable a priori explanation for this technical differentiation, taking into account that, even discarding the sites analysed in this text, we still have some post-500 Ka. Mode 1 assemblages in the European record (3), among others (table 2): Miesenheim I (Turner 1999), Visogliano 40-46 (Abbazzi et al. 2000) and Los Llanos (Arnáiz $\&$ Cuesta 1994). It is necessary, then, to establish a contextual framework for these Mode 1 sites, in order to test whether the label Mode 1 constitutes a simple adaptative answer to variability (Clark \&

(3) Levels (ascending) E1, E, C and Alpha of the Italian site of Notarchirico (Piperno et al. 1999) yielded core and flake industries interstratified with other levels bearing bifaces (A, A1, B, D, $\mathrm{F}$, being $\mathrm{F}$ the oldest in the sequence). Notarchirico exhibits the same chronological problems seen at Isernia: old radiometric ages contradicted by a post-500 Ka. microfaunal collection (Mussi 1995: 32). Taking this into account, a mid-Middle Pleistocene age for the whole sequence seems plausible (Sala 1999). Lithic industries in levels $\mathrm{E}$ and $\mathrm{C}$ are scarce and occurrences in E1 and Alpha (Piperno 1999) can be related with a Mode 2 without handaxes (fig. 3b). Bifaces occur at the lowermost stratum and the whole site may, then, fall within a Mode 2 technology range. 
Schick 2000: 66-67, Domínguez-Rodrigo et al. 2001) or a coherent technological structure (Schick 1994: 584) with a historical meaning.

It is common to call on the functionality of the occupation as a possible cause for technological behaviour. Assuming that Mode 1 represents a minimal technical effort, flexible and efficient enough as to serve for multiple tasks in which an ad hoc technology was required, it is possible to consider this aspect as the cause influencing all the European expedient assemblages (regardless of chronology). The German site of Miesenheim I is illustrative (Turner 1999). The 113 artefacts recovered in this locality, mostly quartzite or quartz cores and nonretouched flakes, dated by biostratigraphy at around 450-400 Ka., have been interpreted as the most effective technological response to a human activity dominated by a secondary scavenging of carcasses obtained by carnivores (cf.: 380 ).

The use of this argument as the absolute cause of the technological diversity we are dealing with is problematic. During the Lower and Middle Palaeolithic there does not seem to exist a clear connection between tool types and function (Beyries 1987). The produced artefacts are highly versatile (Keely \& Toth 1981), depending only on the natural edge forms and cutting potential (VanGijn 1990: 144). The archaeological record confirms this perspective. For instance, the association between large animal accumulations and possible butchery activities has been purported both in Mode 2 sites with handaxes, such as the Spanish site of Áridos (Santonja et al. 1980) or the Italian Notarchirico AB (Piperno et al. 1999: 86-106); in those representing a Mode 2 lacking bifacial tools, as in La Polledrara (Anzidei et al. 1989); and in those related to Mode 1, as exemplifies the Ethiopian site of Gadeb (Clark \& Kurasina 1979: 38) or, in Europe, Isernia (Giusberti \& Peretto 1991).

Raw material has been another important factor of variability often cited. Although this can sometimes be the case, the role played by raw materials has been overestimated (Moloney 1996, Brantingham et al. 2000). Raw material operates mostly on blank dimensions, determining the obtained formats. For the Middle Pleistocene, Isernia is an example definitely constricted by the available flint, barely homogeneous and with many fissures that reduce the fracture possibilities to non-systematic flaking processes (Sozzi et al. 1994). Another example that is worth mentioning is the Spanish site of Cuesta de la Bajada (Santonja et al. 1992), in which the dimensions and availability of raw material (small limestone cobbles) are important factors in the production sequence. The influence of raw material in Lower Pleistocene sites seems to have been less clear. Fuente Nueva 3 and Monte Poggiolo flints show good quality and average dimensions, whereas Atapuerca TD6 exhibits the same variety of raw materials, and in similar proportions, that those selected later or the Modes 2 and 3 assemblages (Mallol 1999).

Finally, it is worth taking into account the migration factor and its possible relation with the fossil information, already mentioned. The validity and general acceptance of the short chronology model might reinforce the idea that archaeological occurrences prior to $500 \mathrm{Ka}$. could be related to an older migration (or migrations) event, around $1 \mathrm{Ma}$. The human fossil record that covers the period between $1 \mathrm{Ma}$. and $500 \mathrm{Ka}$. consists of Homo antecessor remains in Atapuerca TD6, Spain (Bermúdez de Castro et al. 1997) and a cranium in Ceprano, Italy. This last specimen has been identified as a possible bridge between $H$. ergaster/erectus and $H$. heidelbergensis that might represent the first adult cranial remain of $H$. antecessor (Manzi et al. 2001). In both cases morphological differences have been emphasized in relation to $H$. heidelbergensis, whereas phyletic relations with African and Asian ancestors of Lower and Middle Pleistocene have been remarked (Aguirre 2000: 67; Ascenci et al. 2000: 445). These authors propose a link between the European fossil record of this period (1 Ma.-500 $\mathrm{Ka}$.) and hominid populations present in Eurasia since early times- may be through Dmanisi (Gabunia et al. 2001: 167)- as well as African (Ternifine) and Asian (Zhoukoudian) Middle Pleistocene groups. If we accept this perspective as valid (Aguirre 2000: 72), the argument supporting an East Asian origin for European Mode 1 technologies would be reinforced (Rolland 1992).

\section{SUMMARY AND DISCUSSION}

This paper has avoided labelling the Pleistocene industries without handaxes as pre-Acheulean. By doing so, we assume that the concept of technological progress cannot be directly associated to a lineal evolutionary scheme and we doubt that a core and flake industry does always reflect a more primitive stage of human technological achievement. On the contrary, we have preferred to mark out the

T. P., 59, n. ${ }^{\circ} 2,2002$ 
features defining Modes 1 and 2, applying them to those Lower and Middle Pleistocene industries that lack the handaxe, landmark of the Acheulean. It has been possible to observe that most of the Middle Pleistocene sites included by some authors in the Mode 1 group (Villa 2001: 119) exhibit similar operative schemes and configuration/standardization strategies seen in the classical Mode 2. It is possible, perhaps, in regard to the chronological frameworks available, that some of the differential traits observed among this industry might be announcing some of the complex processes that seem to originate in the European Middle Palaeolithic, at around $300 \mathrm{Ka}$.

There are, of course, Middle Pleistocene assemblages that can be linked technologically with Mode 1, although these are less numerous than it has been suggested in other contributions and their final morphology may be markedly constrained by several factors. Accepting the settlement paradigm proposed by the short chronology and the number of fossil evidences associated with $H$. heidelbergensis (some of them significantly linked to the non-biface Mode 2 assemblages cited in this paper), there are firm arguments to infer that the coexistence of both techno-complexes during a post-500 $\mathrm{Ka}$. chronology is due to synchronic variability (Bosinski 1995: 265).

The occurrences older than $500 \mathrm{Ka}$. display Mode 1 features and might be associated with a previous migration event (Aguirre \& Carbonell 2001), although the available data present a heterogeneous quality and still are scarce. Isernia la $\mathrm{Pi}-$ neta (with a problematic chronology that does not allow a clear-cut association with the first or the second radiation events) represents circumstantial evidence, depreciated by the low flint quality. Among the three assemblages included in the Lower Pleistocene, the diagnosis of Fuente Nueva 3 \& Barranco León is limited by the scarcity and heterogeneity of the assemblage (the in situ material belongs to three different archaeological levels). These problems turn this site into precarious evidence. Atapuerca TD6, on the contrary, although a sample recovered from a $6 \mathrm{~m}^{2}$ test excavation, provides more confidence due to the high lithic density $\left(44,66\right.$ objects $\left./ \mathrm{m}^{2}\right)$ patched in a homogeneous 20 $\mathrm{cm}$. stratum. In this case, as well as in Monte Poggiolo, it is unclear that the expedient traits found in this technological behaviour must irrefutably be related to functional patterns or constraints imposed by raw material.
The explanatory hypothesis that this archaeological evidence links with groups related to the Asian Mode 1 tradition could be taken into account. Accepting the available data, the most plausible perspective supports the Asian influence, where Mode 1 might have been preserved until the final Middle Pleistocene (Schick 1994), perhaps due to an early African departure (Swissher et al. 1994; Gabunia et al. 2001) or the loss of former technological capabilities (Toth \& Schick 1993). Whatever the case, it is neccessary to point out that our understanding of the Asian Palaeolithic archaeology (central to this discussion) is as yet unsatisfactory and may be modified by new contributions (Yamei et al. 2000).

Finally, the information provided by Lower Pleistocene European sites remains highly valuable. The empirical information (both archaeological and palaeontological), that needs to be increased, can support a paradigm that enlarges the framework established by the short chronology and helps in understanding the human movements around the Old World during the Lower Pleistocene. Doubtless, this perspective still is rich in questions.

\section{ACKNOWLEGMENTS}

Funding for this research has been provided by the Basque Government, through a postdoctoral fellowship at the University of Indiana, USA.

\section{REFERENCES}

ABBAZZI, L.; FANANI, F.; FERRETTI, M.P. \& ROOK, L. 2000: "New human remains of archaic Homo sapiens and Lower Palaeolithic industries form Visogliano (Duino Ausina, Trieste, Italy)". Journal of Archaeological Science 27: 1173-1186.

AGUIRRE, E. 2000: Evolución humana. Debates actuales y vías abiertas. Real Academia de Ciencias Exactas, Físicas y Naturales. Madrid.

AGUIRRE, E. \& CARBONELL, E. 2001: "Early human expansion into Eurasia: The Atapuerca evidence". Quaternary International 75: 11-18.

ANCONETANI, P.; CROVETTO, C.; FERRARI, M.; GIUSBERTI, G.; LONGO, L.; PERETTO, C. \& VIANELLO, F. 1992: "Nuove ricerche nel giacimento di Isernia la Pineta". Rivista di Scienze Preistoriche 44: 341.

ANZIDEI, A.; ANGELELLI, A.; ARNOLDUS-HUY- 
ZENDVELD, A.; CALOI, L.; PALOMBO, Mĩ. \& SEGRE, A. 1989: "Le gisement Pléistocène de La Polledrara di Cecanibbio (Rome, Italie)". L'Anthropologie 93: 749-782.

ANTONIAZZI, A.; CATTANI, L.; CREMASCHI, M.; FONTANA, L.; PERETTO, C.; ROSENATO, R.; PROLI, F. \& UNGARO, S. 1988: "Le gisement du Paléolithique inférieur de Ca'Belvedere di Monte Poggiolo (Forli, Italie). Résultats préliminaires". L'Anthropologie 92: 629-642.

ARSUAGA, J.L.; GRACIA, A.; MARTÍNEZ, I. \& LORENZO, C. 1996: "The Sima de los Huesos (Sierra de Atapuerca, Spain) cranial evidence and the origin of Neandertals". In E. Carbonell \& M. Vaquero (eds.): The last Neandertals, the first anatomically modern humans. Universitat Rovira i Virgili. Tarragona: 39-49.

ARNÁIZ, M.A. \& CUESTA, A. 1994: "El yacimiento Paleolítico inferior de Los Llanos. San Quirce de Río Pisuerga (Palencia)". Raña 16: 7-11.

ASCENZI, A.; MALLEGNI, F.; MANZI, G.; SEGRE, A. \& SEGRE NALDINI, E. 2000: "A re-apparaisal of Ceprano calvaria affinities with Homo erectus, after the new reconstruction". Journal of Human Evolution 39: 443-450.

ASHTON, N. 1992: "The High Lodge flint industries". In N. Ashton, J. Cook, S. Lewis \& J. Rose (eds.): High Lodge. Excavations by G. de Sieveking, 1962-8, and J. Cook, 1988. British Museum Press. London:124-163.

ASHTON, N. \& McNABB, J. 1992: "The interpretation and context of the High Lodge industries". In N. Ashton, J. Cook, S. Lewis \& J. Rose (eds.): High Lodge. Excavations by G. de Sieveking, 1962-8, and J. Cook, 1988. British Museum Press. London: 164-168.

ASHTON, N.; McNABB, J.; IRVING, B.; LEWIS, S. \& PARFITT, S. 1994: "Contemporaneity of Clactonian and Acheulean flint industries at Barnham, Suffolk". Antiquity 68: 585-589.

AZZAROLI, A.; de GIULI, C.; FICCARELLI, C. \& TORRE, G. 1988: "Late Pliocene to Early mid-Pleistocene mammals in Eurasia: faunal sucession and dispersal events". Palaeogeography, palaeoclimatology, palaeoecology 66: 77-100.

BAR-YOSEF, O. 1998: "Early colonizations and cultural continuities in the Lower Palaeolithic of western Asia". In M. Petraglia \& R. Korisettar (eds.): Early human behaviour in global context. Routledge. London: 221279.

BAR-YOSEF, O. \& KUHN, S. 1999: “The big deal about blades: laminar technology and human evolution". Amercian Anthropologist 101: 322-338.

BERMÚDEZ de CASTRO, J.M.; ARSUAGA, J.L.; CARBONELL, E.; ROSAS, A.; MARTÍNEZ, I. \& MOSQUERA, M. 1997: “A hominid from the Lower Pleistocene of Atapuerca, Spain: Possible ancestor to Neandertals and modern humans". Science 276: 13921395.

T. P., 59, n. ${ }^{\circ} 2,2002$
BEYRIES, S. 1987: Variabilité de l'industrie lithique au Mousterien. Approche fonctionnelle sur quelques gisements françaises. BAR, International Series, 328. Oxford.

BOËDA, E. 1991: “Approche de la variabilité des systèmes de production lithique des industries du Paléolithique inférieur et moyen. Chronique d'une variabilité attendue". Techniques et culture 17-18: 37-39.

BONIFAY, E. \& VANDERMEERSCH, B. (eds.) 1991: Les premiers européens. Editions du C.T.H.S. Paris.

BORDES, F. 1960: "Evolution in the Palaeolithic cultures". In S. Tax (ed.): The evolution of man, mind and society. Aldine. Chicago: 9-110.

BOSINSKI, G. 1995: "Stone artefacts of the European Lower Palaeolithic: a short note". In W. Roebroeks \& T. van Kolfschoten (eds.): The earliest occupation of Europe. University of Leiden. Leiden: 263-268.

BRANTINGHAM, P.; OLSEN, J.; RECH, J. \& KRIVOSHAPKIN, A. 2000: "Raw material quality and prepared core technologies in Northeast Asia". Journal of Archaeological Science 27: 255-271.

BREUIL, H. 1932: "Les industries à éclat du Paléolithique ancien". Préhistoire I (2): 16-190.

CARBONELL, E.; MOSQUERA, M.; RODRÍGUEZ, X.P. \& SALA, R. 1995: "The first human settlement of Europe". Journal of Anthropological Research 51: 107-114.

CARBONELL, E.; MÁRQUEZ, B.; MOSQUERA, M.; OLLÉ, A.; RODRÍGUEZ, X.P.; SALA, R. \& VERGÈS, J.M. 1999a: "El Modo 2 en Galería. Análisis de la industria lítica y sus procesos técnicos". In E. Carbonell, A. Rosas \& J.C. Díez (eds.): Atapuerca: ocupaciones humanas y paleoecología del yacimiento de Galería. Junta de Castilla y León. Valladolid: 299-352.

CARBONELL, E.; GARCÍA-ANTÓN, M.D.; MALLOL, C.; MOSQUERA, M.; OLLÉ, A.; RODRÍGUEZ, X.P.; SAHNOUNI, M.; SALA, R. \& VERGÈS, J.M. 1999b: "The TD6 level lithic industry fron Gran Dolina, Atapuerca (Burgos, Spain): production and use". Journal of Human Evolution 37: 653-693.

CLARK, G. 1969: World Prehistory: a new perspective. Cambridge University Press. London.

CLARK, J.D. 1988: "The Middle Stone Age of East Africa and the beginnings of regional identity". Journal of World Prehistory 2: 235-305.

CLARK, J.D. \& KURASHINA, H. 1979: "Hominid occupation of the East-Central hinghlands of Ethiopia in the Plio-Pleistocene". Nature 282: 33-39.

CLARK, J.D. \& SCHICK, K. 2000: “Acheulean archaeology of the Eastern Middle Awash”. In J. de Heinzelin, J.D. Clark, K. Schick \& W. Gilbert (eds.): The Acheulean and the Plio-Pleistocene deposits of the Middle Awash Valley, Ethiopia. Annales du Musée Royal de l'Afrique Centrale 104. Tervuren: 53-121.

COLTORTI, M.; CREMASCHI, M.; DELITALA, M.; ESU, D.; FORNASERI, M.; McPHERRON, A.; NI- 
COLETTI, M.; Van OTTERLOO, R.; PERETTO, C.; SALA, B.; SCHIMIDT, V. \& SEVINK, J. 1982: "Reversed magnetic polarity at an early Lower Palaeolithic site in Central Italy". Nature 300: 173-176.

COSGROVE, R. 1999: "Forty-two degrees south: the archaeology of Late Pleistocene Tasmania. Palaeoecology and Pleistocene occupation in south central Tasmania". Journal of World Prehistory 13: 357-402.

CROVETTO, C. 1994: "Le industrie litiche. Analisi tecnico-tipologica dei reperti di scavo", in C. Peretto (ed.): Le industrie litiche del giacimento paleolitico di Isernia la Pineta. Cosmo Iannone. Isernia: 183-354.

CROVETTO, C.; FERRARI, M.; PERETTO, C. \& VIANELLO, F. 1994: "Le industrie litiche. La sperimentazione litica". In C. Peretto (ed.): Le industrie litiche del giacimento paleolitico di Isernia la Pineta. Cosmo Iannone. Isernia: 119-182.

CUENCA-BESCÓS, G.; LAPLANA, C. \& CANUDO, J.I. 1999: "Biochronological implications of the Arvicolidae (Rodentia, Mammalia) from the Lower Pleistocene hominid-bearing level of Thinchera Dolina 6 (TD6, Atapuerca, Spain)". Journal of Human Evolution 37: 353-374.

DENNELL, R. \& ROEBROEKS, W. 1996: "The earliest colonization of Europe: the short chronology revisited". Antiquity 70: 535-542.

DOBOSI, V. 1988: "Le site Paléolithique inférieur de Vértesszölös, Hongrie”. L'Anthropologie 92: 1041-1050.

- 1990: "Description of the archaeological material". In M. Kretzoi \& V. Dobosi (eds.): Vértesszölös. Man, site and culture. Akadémiai Kiadó. Budapest: 311-395.

DOMÍNGUEZ-RODRIGO, M.; SERRALLONGA, J.; JUAN-TRESSERRAS, J.; ALCALÁ, L. \& LUQUE, L. 2001: "Woodworking activities by early humans: a plant residue analysis on Acheulian stone tools from Peninj (Tanzania)". Journal of Human Evolution 40: 289-299.

FOLEY, R. 1987: "Hominid species and stone-tool assemblages: how are they related?" Antiquity 61: 380-392.

GABUNIA, L.; ANTÓN, S.; LORDKIPANIDZE, D.; VEKUA, A.; JUSTUS, A. \& SWISSHER, C. 2001: "Dmanisi and dispersal". Evolutionary Anthropology 10: $158-170$

GAMBLE, C. 1999: The Palaeolithic societies of Europe. Cambridge University Press. Cambridge.

GARCÍA-ANTÓN, M. 1995: "Paleovegetación del Pleistoceno medio de Atapuerca a través del análisis polínico". In J.M. Bermúdez de Castro, J.L. Arsuaga \& E. Carbonell (eds.): Evolución humana en Europa y los yacimientos de la Sierra de Atapuerca. Junta de Castilla y León. Valladolid: 147-165.

GIUSBERTI, G. \& PERETTO, C. 1991: "Evidences de la fracturation intentionnelle d'ossements animaux avec moëlle dans le gisement de La Pineta de Isernia (Molise), Italie". L'Anthropologie 95: 765-778.

ISAAC, G.; HARRIS, J. \& KROLL, E. 1997: "The stone artefact assemblages: a comparative study". In G. Isaac \& B. Isaac (eds.): Koobi Fora research project, 5. Clarendon Press. Oxford: 262-299.

KEELY, L. \& TOTH, N. 1981: "Microwear polishes on early stone tools from Koobi Fora, Kenya". Nature 203: 464-465.

KRETZOI, M. \& VÉRTES, L. 1965: “Upper Biharian (Intermindel) pebble-industry occupation site in Western Hungary". Current Anthropology 6: 74-87.

KRETZOI, M. \& DOBOSI, V. (eds.) 1990: Vértesszölös. Man, site and culture. Akadémiai Kiadó. Budapest.

JONES, P.R. 1994: "Results of experimental work in relation to the stone industries of Olduvai Gorge". In M.D. Leakey \& D.A. Roe (eds.): Olduvai Gorge, 5. Cambridge University Press. Cambridge: 254-298.

LEAKEY, M. 1971: Olduvai Gorge: Excavations in Bed I and II, 1960-1963. Cambridge University Press. Cambridge.

LUDWIG, B. \& HARRIS, J. 1998: "Towards a technological reassesment of East African Plio-Pleistocene lithic assemblages". In M. Petraglia \& R. Korisettar (eds.): Early human behaviour in global context. Routledge. London: 84-107.

LUMLEY, H. 1971: Le Paléolithique inférieur et moyen du Midi méditerranéen dans son cadre géologique (BasLanguedoc, Roussillon, Catalogne). Gallia Préhistoire, supplément 5. C.N.S.R. Paris.

- 1976: "Les civilizations du Paléolithique inférieur en Provence". In H. Lumley (ed.): La Préhistoire française, I. C.N.R.S. Paris: 819-851.

- 1982: Les premiers habitants de l'Europe. Muséum National d'Histoire Naturelle. Paris.

MALLOL, C. 1999: "The selection of lithic raw materials in the Lower and Middle Pleistocene levels TD6 and TD10A of Gran Dolina (Sierra de Atapuerca, Burgos, Spain)". Journal of Anthropological Research 55: 385 407.

MANIA, D. 1988: "Le Paléolithique ancien et moyen de la région de la Saale et de l'Elbe, Allemagne de l'Est". L'Anthropologie 92: 1051-1092.

- 1995: "The earliest occupation of Europe: the Elbe-Saale region (Germany)". In W. Roebroeks \& T. van Kolfschoten (eds.): The earliest occupation of Europe. University of Leiden. Leiden: 85-101.

MANIA, D.; MANIA, U. \& VLCEK, E. 1999: "The Bilzingsleben site. Homo erectus, his culture and his ecosphere". In H. Ullrich (ed.): Hominid evolution. Lifestyles and survival strategies. Archaea. Berlin: 293-314.

MANZI, G.; MALLEGNI, F. \& ASCENCI, A. (2001): “A cranium for the earliest Europeans: phylogenetic position of the hominid from Ceprano, Italy". Proceedings of the National Academy of Sciences 98: 10011-10016.

MARTÍNEZ-NAVARRO, B.; TURQ, A.; AGUSTÍ, J. \& OMS, O. 1997: "Fuente Nueva-3 (Orce, Granada, Spain) and the first human occupation of Europe". $\mathrm{Jo}$ urnal of Human Evolution 33: 611-620. 
MOLONEY, N. 1996: "The effects of quartzite pebbles on the technology and typology of Middle Pleistocene assemblages in the Iberian Península". In N. Moloney, L. Raposo \& M. Santonja (eds.): Non-flint stone tools and the Palaeolithic occupation of the Iberian Península. BAR, International Series 649. Oxford: 107-124.

MONCEL, M-H. \& COMBIER, J. 1992: "L'industrie lithique du site Pléistocene moyen d'Orgnac 3 (Ardèche)". Gallia Préhistoire 34: 1-55.

MUSSI, M. 1995: "The earliest occupation of Europe: Italy". In W. Roebroeks \& T. van Kolfschoten (eds.); The earliest occupation of Europe. University of Leiden. Leiden: 27-51.

NEWCOMER, M. “Comments to Ohel, M. 1979”. Current Anthropology 20: 717-718.

OHEL, M. 1979: "The Clactonian: an independent complex or an integral part of the Acheulean?". Current Anthropology 20: 685-713.

OMS, O; PARÉS, J.M.; MARTÍNEZ-NAVARRO, B.; AGUSTÍ, J.; TORO, I.; MARTÍNEZ-FERNÁNDEZ, G. \& TURQ, A. 2000: "Early human occupation of Western Europe: Paleomagnetic dates for two paleolithic sites in Spain". Proceedings of the National Academy of Sciences 19: 10666-10670.

PARÉS, J.M. \& PÉREZ-GONZÁLEZ, A. 1995: “Paleomagnetic age for hominid fossils at Atapuerca Archaeological site, Spain". Science 269: 830-832.

- (1999). "Magnetochronology and stratigraphy at Gran Dolina section, Atapuerca (Burgos, Spain)". Journal of Human Evolution 37: 325-342.

PERETTO, C.; ORNELLA AMORE, F.; ANTONIAZZI, A.; ANTONIAZZI, A.; J-BAHAIN, J-J.; CATTANI, L.; CAVALLINI, E.; ESPOSITO, P.; FALGUÈRES, C.; GAGNEPAIN, J.; HEDLEY, I.; LAURENT, M.; LEBRETON, V.; LONGO, L.; MILLIKEN, S.; MONEGATTI, P.; OLLÉ, A.; PUGLIESE, N.; MISKOVSKY-RENAULT, J.; SOZZI, M.; UNGARO, S.; VANNUCCI, S.; VERGÈS, J.M.; WAGNER, J-J. \& YOKOYAMA, Y. 1998: "L'industrie lithique de Ca'Belvedere di Monte Poggiolo: stratigraphie, matière première, typologie, remontages et traces d'utilization". L'Anthropologie 102: 243-365.

PETRONIO, C. \& SARDELLA, R. 1999: "Biochronology of the Pleistocene mammal fauna from Ponte Galeria (Rome) and remarks ot the Middle Galerian faunas". Rivista Italiana di Paleontologia e Stratigrafia 105: 155-164.

PIPERNO, M. 1999: "Studio tecnico-tipologico e tipometrico delle schelle e degli strumenti su scheggia del livello Alfa". In M. Piperno (ed.): Notarchirico. Un sito del Pleistocene medio iniziale nel bacino di Venosa. Ossana. Venosa: 309-337.

PIPERNO, M.; CASSOLI, F.; TAGLIACOZZO, A. \& FIORE, I. 1999: "I livelli della serie di Notarchirico". In M. Piperno (ed.): Notarchirico. Un sito del Pleistocene medio iniziale nel bacino di Venosa. Ossana. Venosa: 75-135.

RAYNAL, J.P.; SBIHI ALAOUI, F.; GERAADS, D.; MAGOGA, L. \& MOHI, A. 2001: "The erarliest occupation of North-Africa. The Moroccan perspective". Quaternary International 75: 65-75.

RIGHMIRE, G. P. 1996: "The human cranium from Bodo, Ethiopia: evidence for speciation in the Middle Pleistocene?" Journal of Human Evolution 31: 21-39.

ROBERTS, M.; GAMBLE, C. \& BRIDGLAND, D. 1995: "The earliest occupation of Europe: the British Isles". In W. Roebroeks \& T. van Kolfschoten (eds.): The earliest occupation of Europe. University of Leiden. Leiden: 165-191.

ROBERTS, M.; STRINGER, C. \& PARFITT, S. 1994: “A hominid tibia from Middle Pleistocene sediments at Boxgrove, UK". Nature 369: 311-313.

ROE, D.A. 1982: "The transition from Lower to Middle Palaeolithic, with particular reference to Britain". In A. Ronen (ed.): The transition from Lower to Middle Palaeolithci and the origin of modern man. BAR, International Series 151. Oxford: 177-191.

- 1995: "The Orce basin (Andalucía, Spain) and the initial Palaeolithic of Europe". Oxford Journal of Archaeology 14: 1-13.

ROEBROEKS, W. \& VAN KOLFSCHOTEN, T. 1994: "The earliest occupation of Europe: a short chronology". Antiquity 68: 489-503.

- (eds.) 1995: The earliest occupation of Europe. University of Leiden. Leiden.

- 1998: "The earliest occupation of Europe: a voew from the north". In E. Aguirre (ed.): Atapuerca y la evolución humana. Fundación Areces. Madrid: 153-168.

ROLLAND, N. 1992: "The Palaeolithic colonization of Europe: an archaeological and biogeographic perspective". Trabajos de Prehistoria 49: 69-111.

- 1999: "The Middle Palaeolithic as development stage: evidence from technology, subsistence, settlement systems and hominid socio-ecology". In H. Ullrich (ed.): Hominid evolution. Lifestyles and survival strategies. Archaea. Berlin: 315-334.

SALA, B. 1999: "Nuovi dati sulla microteriofauna di Notarchirico". In M. Piperno (ed.): Notarchirico. Un sito del Pleistocene medio iniziale nel bacino di Venosa. Osana. Venosa: 439-441.

SANTONJA, M. 1995: "El Paleolítico inferior en la Submeseta norte y en el entorno de Atapuerca. Balance de los conocimientos en 1992". In J.M. Bermúdez de Castro, J.L. Arsuaga \& E. Carbonell (eds.): Evolución humana en Europa y los yacimientos de la Sierra de Atapuerca. Junta de Castilla y León. Valladolid: 421-444.

SANTONJA, M.; LÓPEZ, N. \& PÉREZ-GONZÁLEZ, A. (eds.) 1980: Ocupaciones achelenses en el Valle del Jarama (Arganda, Madrid). Diputación de Madrid. Madrid.

SANTONJA, M.; MOISSENET, E. \& PÉREZ-GONZÁ-

T. P., 59, n. ${ }^{\circ} 2,2002$ 
LEZ, A. 1992: "Cuesta de la Bajada (Teruel). Nuevo sitio Paleolítico inferior". Boletín del Seminario de Arte y Arqueología LVIII: 25-45.

SCHICK, K. 1994: “The Movius line reconsidered. Perspectives on the Earlier Paleolithic of Eastern Asia". In R. Corruccini \& R. Ciocon (eds.): Integrative paths to the past. Prentice Hall. New Jersey: 569-595.

SCHICK, K. \& ZHUAN, D. 1993: "Early Paleolithic of China and Eastern Asia". Evolutionary Anthropology 2: 22-34.

SCHICK, K.; TOTH, N.; QI, W.; CLARK, J.D. \& ETLER, D. 1991: "Archaeological perspectives in the Nihewan Basin, China". Journal of Human Evolution 21: 13-26.

SCHWARCZ, H.; GRÜN, R.; LATHAM, A.; MANIA, D. \& BRUNNACKER, K. 1988: "The Bilzingsleben archaeological site: New dating evidence". Archaeometry 30: 5-17.

SEMAW, S. 2000: "The world's oldest stone artefacts from Gona, Ethiopia: their implications for understanding stone technology and patterns of human evolution between 2,6-1,5 million years ago". Journal of Archaeological Science 27: 1197-1214.

SOZZI, M.; VANNUCCI, S. \& VASELLI, O. 1994: "Le industrie litiche. La materia prima impiegata nella scheggiatura". In C. Peretto (ed.): Le industrie litiche del giacimento paleolitico di Isernia la Pineta. Cosmo Iannone. Isernia: 45-86.

SVOBODA, J. 1987: "Lithic industries of the Arago, Vértesszöllös and Bilzingsleben hominids: comparison and evolutionary interpretation". Current Anthropology 28: 219-227.

SWISHER, C.; CURTIS, J.; JACOB, G.; GETTY, T. y SUPRIJO, A. 1994: "Age of the earliest known hominids in Java, Indonesia". Science 263: 11118-1121.

TEXIER, P-J. \& ROCHE, H. 1995: "The impact of predetermination on the development of some acheulean chaînes opératoires". In J.M. Bermúdez de Castro, J.L. Arsuaga \& E. Carbonell (eds.): Evolución humana en Europa y los yacimientos de la Sierra de Atapuerca. Junta de Castilla y León. Valladolid: 403-420.

THIEME, H. 1999: "Lower palaeolithic throwing spears and other wooden implements from Schöningen. Germany". In H. Ullrich (ed.): Hominid evolution. Lifestyles and survival strategies. Archaea. Berlin: 383-395.

TIEU. L. 1991: Palaeolithic pebble industries in Europe. Akadémiai Kiadó. Budapest.

TORRENCE, R. 1989: “Tools as optimal solutions". In R. Torrence (ed.): Time, energy and stone tools. Cambridge University Press. Cambridge: 1-16.

TOTH, N. 1985: "The Oldowan reassessed: a close look at Early Stone artifacts". Journal of Achaeological Science 12: 101-120.
- 1987: "Behavioural inferences from Early Stone artifact aeemblages: an experimental model". Journal of $\mathrm{Hu}$ man Evolution 16: 763-787.

TOTH, N. y SCHICK, k. 1993: "Early stone industries and inferences regarding language and cognition". In K. Gibson y T. Ingold (eds.): Tools, language and cognition. Cambridge University Press. Cambridge: 346362.

TURNER, A. 1992: "Large carnivores and earliest European hominids: changing determinants of resources availability during the Lower and Middle Pleistocene". Journal of Human Evolution 22: 109-126.

TURNER, E. 1999: "The problems of interpreting hominid subsistence strategies at Lower Palaeolithic sites: Miesenheim I. A case study from the Central Rhineland of Germany". In H. Ullrich (ed.): Hominid evolution. $\mathrm{Li}$ festyles and survival strategies. Archaea. Berlin: 365382.

VAN GIJN, A. L. 1990: The wear and the tear of flint. Principles of functional analysis applied to Dutch neolithic assemblages. University of Leiden. Leiden.

VALOCH, K. 1995: "The earliest occupation of Europe: Eastern Central and Southeastern Europe". In W. Roebroeks \& T. van Kolfschoten (eds.): The earliest occupation of Europe. University of Leiden. Leiden: 67-84.

VÉRTES, L. 1975: "The Lower Palaeolithic site of Vértesszöllös, Hungary”. In R. Bruce-Mitford (ed.): Recent Archaeological Excavations in Europe. Routledge. London: 287-301.

VILLA, P. 1983: Terra Amata and the Middle Pleistocene archaeological record of Southern France. University of California Press. Berkeley.

- 2001: "Early Italy and the colonization of Western Europe". Quaternary International 75: 113-130.

WENBAN-SMITH, F. 1998: "Clactonian and Acheulean industries in Britain: their chron ology and significance reconsidered". In N. Ashton, H. Healy y P. Pettitt (eds.): Stone Age archaeology. Essays in honour of John Wymer. Oxbon Monograph. Oxford: 90-104.

YAMEI, H.; POTTS, R.; BAOYIN, Y.; ZHENGTANG, G.; DEINO, A.; WEI, W.; CLARK, J.; GUANGMAO, X. \& WEIWEN, H. 2000: "Mid-Pleistocene Acheuleanlike stone technology of the Bose Basin, South China". Science 287: 1622-1626.

YOKOYAMA, Y.; BAHAIN, J-J.; FALGUERES, C. \& GAGNEPAIN, J. 1992: "Tentative de datation par la méthode de la résonance de spin électronique (ESR) de sédiments quaternaires de la région de Forli". Il piú antico popolamento della Valle Padana nel quadro delle conoscenze europea. Jaca Book. Milano: 337 346. 